\title{
Experimental Study On Lateral Load Capacity of Bamboo RC Beam Column Joints Strengthened By Bamboo Mechanical Anchors
}

\author{
B. Sri Umniati ${ }^{1,4,}{ }^{*}$, Sri Murni Dewi ${ }^{2}$, Nindyawati ${ }^{1,4}$, and Gatot Adi Susilo ${ }^{3}$ \\ ${ }^{1}$ Civil Engineering Department, Universitas Negeri Malang, Malang, Indonesia \\ ${ }^{2}$ Civil Engineering Department, Brawijaya University, Malang, Indonesia \\ ${ }^{3}$ Architectural Department, Institut Teknologi Nasional, Malang, Indonesia \\ ${ }^{4}$ Konsorsium RisetGeopolimer Indonesia (KORIGI), Lab Beton dan Bahan Bangunan ITS, Surabaya, \\ Indonesia
}

\begin{abstract}
In this paper, the prospective of bamboos which available abundantly especially in Indonesia as rebars and mechanical anchors are studied. And also the endurance of the bamboos mechanical anchors to withstand cyclic loading were observed. Nine classes of bamboos bar were evaluated: consist of 3 different anchors ( 0,4 and 8 anchors) and 3 different compressive strength (19.19 MPa, 29.61 MPa and $37.96 \mathrm{MPa}$ ) means $3 \times 3$ parameters. The results show that the lateral load capacity increased significantly with the present of bamboo anchors specimens: $26.04 \%$ for 4 anchors specimens (C2) and $25 \%$ for the 8 anchors specimens (C3) compared to zero anchor specimens (C1). On the other hand, the compressive strength of concrete have no significant effects to the lateral load capacity. Overall it can be concluded that, bamboo can be used as mechanical anchorage to strengthen beam column joint.
\end{abstract}

\section{Introduction}

Many structures collapse during earthquakes due to severe damage to beam column connections, whereas, their other parts remain unaffected. Therefore, it is necessary to strengthen beam column joints by using mechanical anchorages in order to better the overall performance of concrete structures. This study aimed to find out whether bamboo mechanical anchor could be used as an anchorage in beam column joints to withstand earthquakes.

The use of bamboo as a significant alternative to steel bar in concrete structure is an interesting subject for research as it gives many benefits, for example in the matter of strength, galah bamboo has a tensile strength of $253 \mathrm{MPa}$, the same tensile strength as steel reinforcement of around $240 \mathrm{MPa}$ to $400 \mathrm{MPa}$ [1]. From the aspect of costs, bamboo is far cheaper than steel but has the same strength. Furthermore, it is an abundant and renewable resource found in all tropical regions of the world. Several species of bamboo have been used by the authors as bars in concrete such as 'petung' (Dendrocalamus asper), 'ori' (Bambusa

\footnotetext{
*Corresponding author: b.sri.umniati.ft@um.ac.id
} 
blumeana) and 'tali' (Gigantochloa apus). These are 3 types of bamboo have proved to be highly recommended for replacing steel bars in concrete from previous study [2-7]. For this study, the bamboo was prepared as follows: 1) the bamboo was cut and split into the sizes required and then dried for about 28 days ; 2) when dry, it was painted with 2 coats of paint used for wood as water proofing with an interval 24 hours between coats ; 3) immediately after the second coat, the freshly painted bamboo was buried in sand. Sand adheres to the bamboo and improves the binding of the concrete to the bamboo and, as soon as the paint is dry, the bamboo is ready for use as bars in concrete [8].

Available data on structural damage due to earthquakes indicates that it is most prevalent in beam column joints, whereas, other parts are relatively unaffected with a few hairline cracks in those areas closest to beam column joints. These findings are supported by the author's previous experiments [4] where bamboo reinforcements to concrete frame, which had already been damaged by cyclical loads from a UTM axial test results indicated that these columns could bear axial loads of between 12 and 17.5 tons. These results are slightly lower than the theoretical axial load capacity [9] for the column sections of 18 tons, showing that within the structure of the columns, the bamboo reinforcements remained adhered to the concrete and that the column sections had functioned well. However, therefore, there are still room for improvement and further studies are required to into beam column joints to make them even better in order to ensure that the whole structure is stronger. Conventional beam column joints commonly use development hooks (are constructed from longitudinal steel bars bent into an ' $\mathrm{L}$ ' shape at angle of $90^{\circ}$. But the weakness of this type, apart from being understrength, can also give rise to reinforcement congestion especially in exterior joints [10-13]. Thus the use of alternative methods such as mechanical anchors or 'headed bars' $[10,13]$ that are combined with vertically distributed reinforcements [12] to optimize structural strength as a whole. The aim of this study was (1) to discover the characteristics of the relationship between load $(\mathrm{P})$ and displacement $(\Delta)$ on beam column joints under cyclic loads using quasi-cyclic loading test; (2) to find out the effect of concrete strength and the number of anchors installed on their capacity to withstand earthquakes loads; and (3) to draw up models of P- $\Delta$ relationships of beam column joints.

\section{Experimental program}

\subsection{Specimens}

The specimens tested were ' $\mathrm{T}$ ' shaped interior beam column joints. The variables were concrete strength (variable A), and the total number of anchors installed (variable C). In this study, a group of a $3^{2}$ factorial design [14] was employed. 9 specimens were made in this group. This group had 2 factors (A and C) at 3 levels (low, medium, and high), is shown in Table 1. Details of the specimens are presented in Figure 1.

Table 1. Specimens coding.

\begin{tabular}{|c|c|c|c|}
\hline $\begin{array}{c}\text { Number of } \\
\text { anchors (headed } \\
\text { bars) }\end{array}$ & $\begin{array}{c}\text { Comp. strength [fe'] } \\
\mathbf{A 1}=\mathbf{1 9 . 1 9} \mathbf{M P a}\end{array}$ & $\begin{array}{c}\text { Comp. strength [fc'] } \\
\mathbf{A 2}=\mathbf{2 9 . 6 1} \mathbf{M P a}\end{array}$ & $\begin{array}{c}\text { Comp. strength [fe'] } \\
\mathbf{A 3}=\mathbf{3 7 . 9 6} \mathbf{~ M P a}\end{array}$ \\
\hline $\mathbf{C} 1=\mathbf{0}$ & $\mathrm{A} 1 \mathrm{C} 1$ & $\mathrm{~A} 2 \mathrm{C} 1$ & $\mathrm{~A} 3 \mathrm{C} 1$ \\
\hline $\mathbf{C} 2=\mathbf{4}$ anchors & $\mathrm{A} 1 \mathrm{C} 2$ & $\mathrm{~A} 2 \mathrm{C} 2$ & $\mathrm{~A} 3 \mathrm{C} 2$ \\
\hline $\mathbf{C 3}=\mathbf{8}$ anchors & $\mathrm{A} 1 \mathrm{C} 3$ & $\mathrm{~A} 2 \mathrm{C} 3$ & $\mathrm{~A} 3 \mathrm{C} 3$ \\
\hline
\end{tabular}




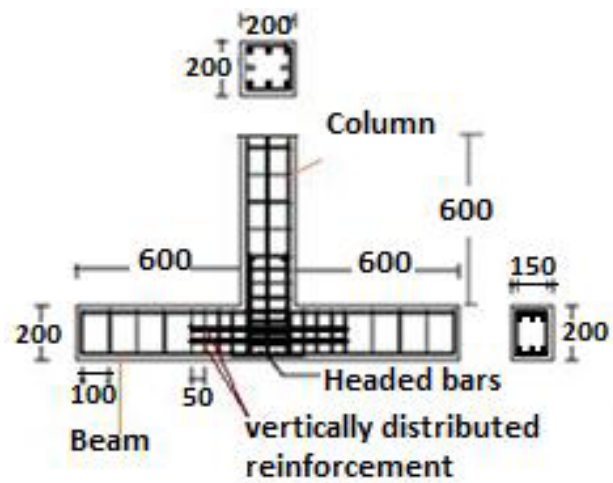

(a)

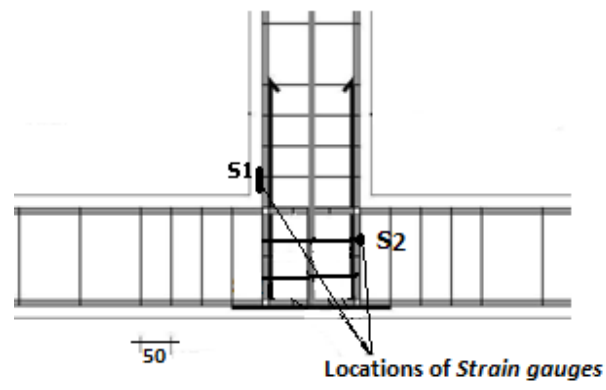

(b)

Fig. 1. a). Detail of specimen (unit in mm); b). Strain Gauges locations

The bamboo reinforcement used in these experiments were made from 3-year-old Bambusa blumeana (Indonesian's name: 'Ori'), taken from the base up to 6 metres. The tension yield strength of the Ori bamboo used was $94.778 \mathrm{MPa}$ and its ultimate yield strength was $124.26 \mathrm{MPa}$. The steel bars used for shear reinforcements were $6 \mathrm{~mm}$ in diameter with a yield strength of 419.17 MPa and an ultimate yield strength of 609.07 MPa. The parameters measured were (1) cyclical load, namely, the lateral load applied to the test subjects; and (2) deformations in test subjects due to cyclical loads in the form of lateral displacement of the column ends and bases, strain in bamboo bars and in shear reinforcements, and the form of cracks patterns.

\subsection{Test set-up}

The set-up for the instruments used to measure cyclical and monotonic loads, as well as the application of force are shown in Fig. 2.

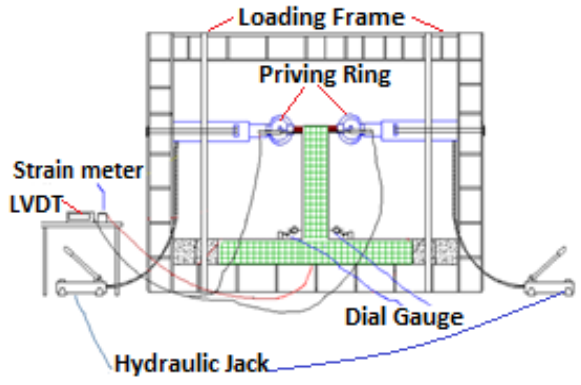

(a)

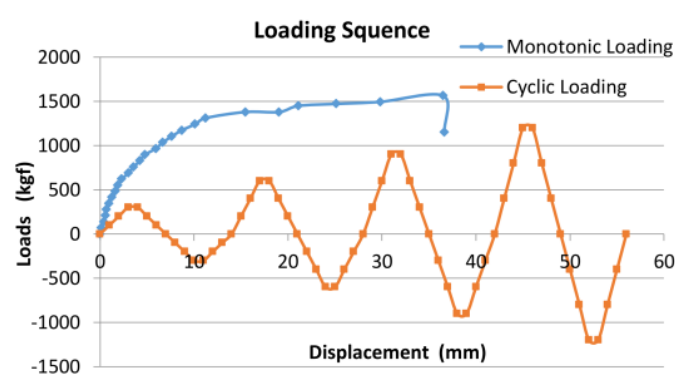

(b)

Fig. 2. a). Test Set-up; b). Loading Squence

\subsection{Test procedure}

The beam column joints were subjected to lateral cyclic loads. Load intervals were adjusted for the proving ring. The first interval reading was $3 \times 100 \mathrm{kgf}$. For the second and third readings, force was applied twice and three times respectively. Due to page limits for 
publication, only graphs showing the relationship of lateral loads (P) to displacements $(\Delta)$ are shown in this paper.

\section{Results}

The test results obtained from the cyclical loads applied enabled a graph to be plotted showing the relationship between the parameters measured for each load application. Each cycle load was plotted in one colour. The energy dissipations is computed by summing the curve area of each cycle (not included here). For test subjects $\mathrm{A} 1 \mathrm{C} 1, \mathrm{~A} 1 \mathrm{C} 2$ and $\mathrm{A} 1 \mathrm{C} 3$, the graphs of the relationship between lateral loads and lateral displacement shown Figure $3 \mathrm{a}, \mathrm{b}$ and $\mathrm{c}$.

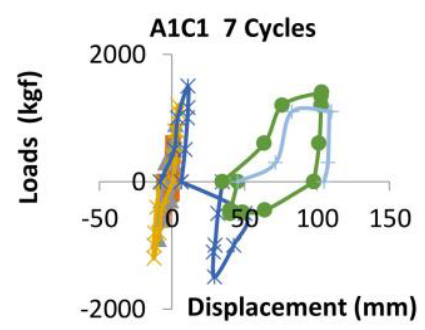

(a)

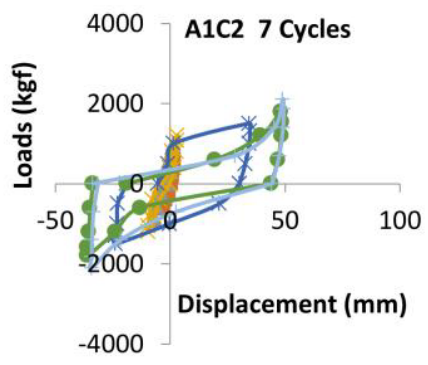

(b)

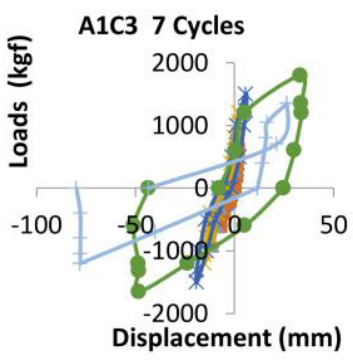

(c)

Fig. 3. The relationship between lateral load $(\mathrm{P})$ and lateral displacement for test subjects a) A1C1; b) $\mathrm{A} 1 \mathrm{C} 2$ and c) $\mathrm{A} 1 \mathrm{C} 3$.

Figure 3 show the level of lateral displacement for each load application in concrete compressive strength $\mathrm{A} 1$ and the number of bamboo anchors installed for test subjects $\mathrm{C} 1, \mathrm{C} 2$ and $\mathrm{C} 3$ respectively. For test subjects $\mathrm{A} 2 \mathrm{C} 1, \mathrm{~A} 2 \mathrm{C} 2$, an $\mathrm{A} 2 \mathrm{C} 3$ the graphs of the relationship between lateral loads and lateral displacement are indicated in figure $4 \mathrm{a}, \mathrm{b}$, and $\mathrm{c}$.

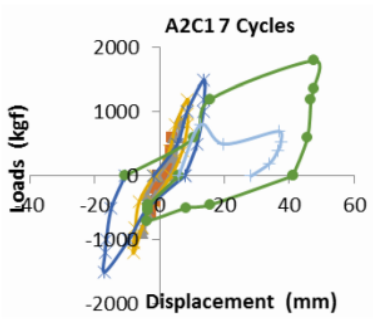

(a) $\mathrm{A} 2 \mathrm{C} 1$

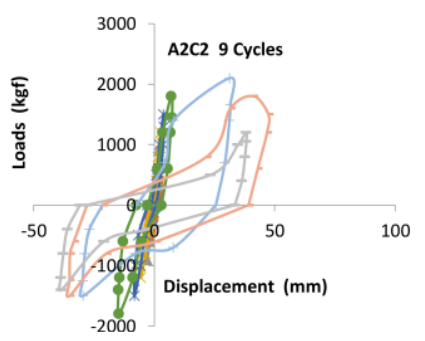

(b) $\mathrm{A} 2 \mathrm{C} 2$

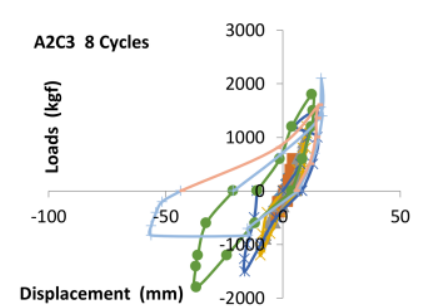

(c) $\mathrm{A} 2 \mathrm{C} 3$

Fig. 4. The relationship between lateral load (P) and lateral displacement, for $\mathrm{A} 2$ test subjects

Figure 4 demonstrates lateral displacement levels for each lateral load application in concrete compressive strength $\mathrm{A} 2$ and the number of bamboo anchors installed in test subjects $\mathrm{C} 1, \mathrm{C} 2$ and $\mathrm{C} 3$ respectively. For test subjects $\mathrm{A} 3 \mathrm{C} 1, \mathrm{~A} 3 \mathrm{C} 2$ and $\mathrm{A} 3 \mathrm{C} 3$ the data for the relationship between lateral loads and displacement are indicated in Figure $5 \mathrm{a}, \mathrm{b}$ and $\mathrm{c}$. 


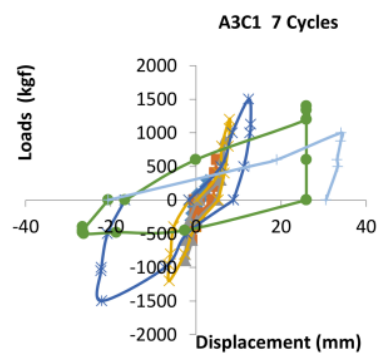

(a) $\mathrm{A} 3 \mathrm{C} 1$

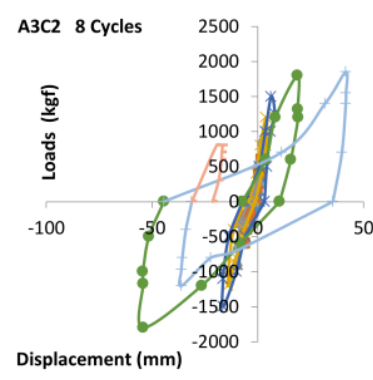

(b) $\mathrm{A} 3 \mathrm{C} 2$

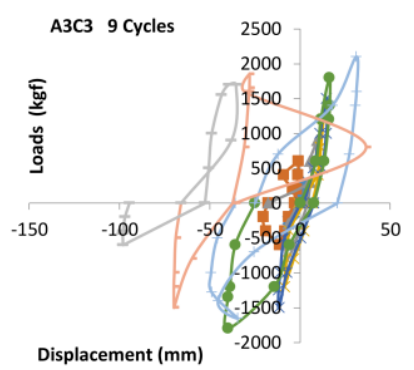

(c) $\mathrm{A} 3 \mathrm{C} 3$

Fig. 5. The relationship between lateral load (P) and lateral displacement for A3 test subjects

The maximum compression and tension lateral loads for each test subjects, summarized in Table 2.

Table 2. Maximum loads, compression and tension.

\begin{tabular}{|c|c|c|}
\hline Specimen & Maximum Compression Load [kgf] & Maximum Tension Load [kgf] \\
\hline A1C1 & 1500 & 1500 \\
\hline A1C2 & 2100 & 2100 \\
\hline A1C3 & 1800 & 1650 \\
\hline A2C1 & 1800 & 1500 \\
\hline A2C2 & 2100 & 1500 \\
\hline A2C3 & 2100 & 1800 \\
\hline A3C1 & 1500 & 1300 \\
\hline A3C2 & 1850 & 1800 \\
\hline A3C3 & 2100 & 1800 \\
\hline
\end{tabular}

\subsection{Cracks pattern}

In the test on the beam column joints using cyclical lateral loads, the form of the cracks that appeared in the test each of beam column joints after the test were finished was noted. The form of these cracks demonstrate the type of collapse that occurred in them. Figure $6 \mathrm{a}, \mathrm{b}$ and c show crack form for beam column joints as well as the total anchors installed for test subjects $\mathrm{C} 1, \mathrm{C} 2$ and $\mathrm{C} 3$ respectively for concrete compressive strength $\mathrm{A} 1$.

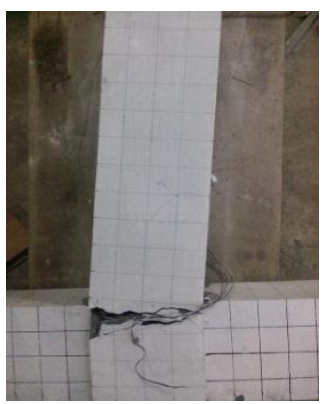

(a)

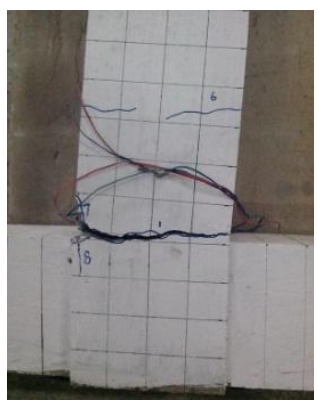

(b)

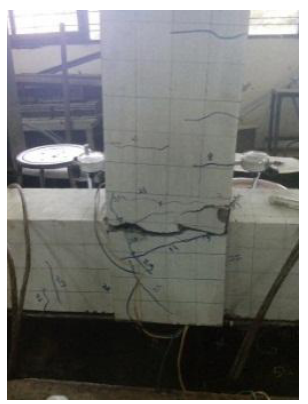

(c)

Fig. 6. Cracks pattern in a) $\mathrm{A} 1 \mathrm{C} 1$; b) $\mathrm{A} 1 \mathrm{C} 2$ and c) $\mathrm{A} 1 \mathrm{C} 3$

Figure $7 \mathrm{a}, \mathrm{b}$ and $\mathrm{c}$ crack form in beam column joints, for concrete compressive strength $\mathrm{A} 2$ as well as bamboo anchors installed in $\mathrm{C} 1, \mathrm{C} 2$ and $\mathrm{C} 3$ respectively. 


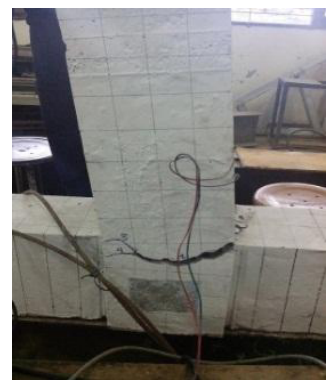

(a)

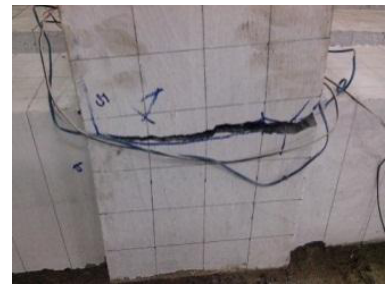

(b)

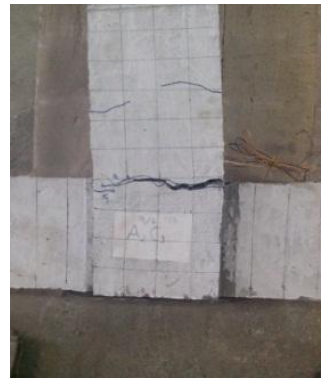

(c)

Fig. 7. The Cracks pattern in a) $\mathrm{A} 2 \mathrm{C} 1$; b) $\mathrm{A} 2 \mathrm{C} 2$; c) $\mathrm{A} 2 \mathrm{C} 3$.

Figure $8 \mathrm{a}, \mathrm{b}$ and $\mathrm{c}$ crack form in beam column joints, test subjects $\mathrm{C} 1, \mathrm{C} 2$ and $\mathrm{C} 3$ respectively for $\mathrm{A} 3$ concrete compressive strength.

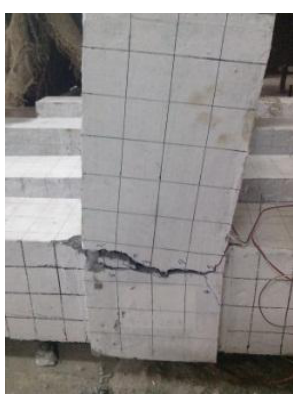

(a)

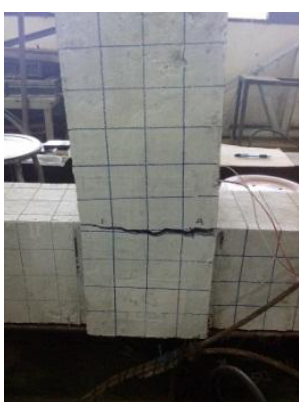

(b)

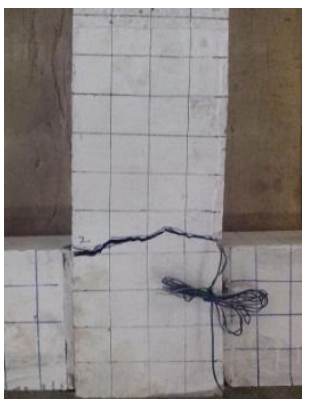

(c)

Fig. 8. The form of the cracks in test subjects a) $\mathrm{A} 3 \mathrm{C} 1$; b) $\mathrm{A} 3 \mathrm{C} 2$ an c) $\mathrm{A} 3 \mathrm{C} 3$

\section{Discussion of results}

The above graphs demonstrate the relationship between lateral load and deformation in the tested beam column joints as well as maximum compression and tension lateral loads for each test subjects, summarized in Table 3 and Table 4.

Table 3. Maximum compression lateral loads for concrete compressive strength $\mathrm{A} 1, \mathrm{~A} 2$ and $\mathrm{A} 3$ and for C1. C2 and C3 totals for bamboo anchors installed.

\begin{tabular}{|c|c|c|c|c|c|}
\hline $\begin{array}{c}\text { Number of } \\
\text { anchors } \\
\text { installed }\end{array}$ & $\begin{array}{c}\mathbf{A 1} \\
{[\mathbf{k g f}]}\end{array}$ & $\begin{array}{c}\mathbf{A 2} \\
{[\mathbf{k g f}]}\end{array}$ & $\begin{array}{c}\mathbf{A 3} \\
{[\mathbf{k g f}]}\end{array}$ & $\begin{array}{c}\text { Total } \\
{[\mathbf{k g f}]}\end{array}$ & $\begin{array}{c}\text { Difference } \\
{[\%]}\end{array}$ \\
\hline $\mathrm{C} 1=0$ & $\mathrm{~A} 1 \mathrm{C} 1=1500$ & $\mathrm{~A} 2 \mathrm{C} 1=1800$ & $\mathrm{~A} 3 \mathrm{C} 1=1500$ & $\Sigma \mathrm{AiC} 1=4800$ & 0 \\
\hline $\mathrm{C} 2=4$ & $\mathrm{~A} 1 \mathrm{C} 2=2100$ & $\mathrm{~A} 2 \mathrm{C} 2=2100$ & $\mathrm{~A} 3 \mathrm{C} 2=1850$ & $\Sigma \mathrm{AiC} 2=6050$ & 26.04167 \\
\hline $\mathrm{C} 3=8$ & $\mathrm{~A} 1 \mathrm{C} 3=1800$ & $\mathrm{~A} 2 \mathrm{C} 3=2100$ & $\mathrm{~A} 3 \mathrm{C} 3=2100$ & $\Sigma \mathrm{AiC} 3=6000$ & 25 \\
\hline Total & $\Sigma \mathrm{A} 1 \mathrm{Ci}=5400$ & $\Sigma \mathrm{A} 2 \mathrm{C} \mathrm{i}=6000$ & $\Sigma \mathrm{A} 3 \mathrm{Ci}=5450$ & & \\
\hline $\begin{array}{c}\text { Difference } \\
{[\%]}\end{array}$ & $\mathbf{0}$ & $\mathbf{1 1 . 1 1}$ & $\mathbf{0 . 9 3}$ & & \\
\hline
\end{tabular}


Table 3 indicates that the highest $\mathrm{P}$ max. from all 3 concrete compressive strengths was achieved by the $\mathrm{C} 2$ ( 4 anchors) test subjects. Also, the highest $\mathrm{P}$ max. values were obtained by the $\mathrm{A} 2$ concrete compressive strength. The deformation, as shown in the graphs for the relationship between load $(\mathrm{P})$ and displacement $(\Delta)$ and crack formation demonstrates that in test subjects of higher concrete compressive strength without anchors, this did not significantly affect the deformation that occurred. Whereas, for test subjects with anchors installed endurance to lateral loads increased, these test subjects became more ductile as proved by their withstanding repeated cycles of load applications and by their crack formation (without or with hairline cracks of column). Maximum load equation, namely, $\mathrm{P}$ max. $=1600+158.3 \mathrm{C}-13.54 \mathrm{C}^{2}$ with a coefficient regression of $\mathrm{R}^{2}=0.674$ where $\mathrm{C}$ is amount of anchors installed. And the P max. values for tension are shown in Table 4.

Table 4. Maximum lateral load (tension) for concrete compressive strength A1, A2 and A3 and for C1, $\mathrm{C} 2$ and $\mathrm{C} 3$ totals for installed anchors, as well as the lowest difference levels.

\begin{tabular}{|c|c|c|c|c|c|}
\hline $\begin{array}{c}\text { Number of } \\
\text { anchors } \\
\text { installed }\end{array}$ & $\begin{array}{c}\mathbf{A} 1 \\
{[\mathbf{k g f}]}\end{array}$ & $\begin{array}{c}\mathbf{A 2} \\
{[\mathbf{k g f}]}\end{array}$ & $\begin{array}{c}\mathbf{A 3} \\
{[\mathbf{k g f}]}\end{array}$ & $\begin{array}{c}\text { Total } \\
{[\mathbf{k g f}]}\end{array}$ & $\begin{array}{c}\text { Difference } \\
{[\%]}\end{array}$ \\
\hline $\mathbf{C} 1=\mathbf{0}$ & $\mathrm{A} 1 \mathrm{C} 1=1500$ & $\mathrm{~A} 2 \mathrm{C} 1=1500$ & $\mathrm{~A} 3 \mathrm{C} 1=1300$ & $\Sigma \mathrm{AiC} 1=4300$ & $\mathbf{0}$ \\
\hline $\mathbf{C} 2=\mathbf{4}$ & $\mathrm{A} 1 \mathrm{C} 2=2100$ & $\mathrm{~A} 2 \mathrm{C} 2=1500$ & $\mathrm{~A} 3 \mathrm{C} 2=1800$ & $\Sigma \mathrm{AiC} 2=5400$ & $\mathbf{2 5 . 5 8 1 4}$ \\
\hline $\mathbf{C 3}=\mathbf{8}$ & $\mathrm{A} 1 \mathrm{C} 3=1650$ & $\mathrm{~A} 2 \mathrm{C} 3=1800$ & $\mathrm{~A} 3 \mathrm{C} 3=1800$ & $\Sigma \mathrm{AiC} 3=5250$ & $\mathbf{2 2 . 0 9 3 0 2}$ \\
\hline Total & $\Sigma \mathrm{A} 1 \mathrm{Ci}=5250$ & $\Sigma \mathrm{A} 2 \mathrm{Ci}=4800$ & $\Sigma \mathrm{A} 3 \mathrm{Ci}=4900$ & 14950 & \\
\hline $\begin{array}{c}\text { Difference } \\
{[\%]}\end{array}$ & $\mathbf{0}$ & $\mathbf{- 8 . 5 7}$ & $\mathbf{- 6 . 6 7}$ & & \\
\hline
\end{tabular}

For the above tension values, the $\mathrm{P}$ max. was $1433+143.7 \mathrm{C}-13.02 \mathrm{C}^{2}$ with a regression coefficient of $\mathrm{R}^{2}=0.517$.

\section{Summary}

From research results and discussion, the following conclusions can be made:

1. The installation of bamboo mechanical anchors to beam column joints increased lateral load capacity by $26.04 \%$ for compression lateral load (Table 2 ) and $25.58 \%$ for tension lateral load (Table 3), and reduced deformation.

2. The test with the optimum number of bamboo anchors was $A 2\left(\mathrm{fc}^{\prime}=29,61 \mathrm{MPa}\right)$ with 4 anchors (C2).

3. The regression model for lateral load capacity for number of anchors installed variables, are as follows: Under compression lateral load, the $\mathrm{P}$ max was $1600+158.3 \mathrm{C}-13.54 \mathrm{C}^{2}$ with a coefficient regression of $R^{2}=0.674$ where $C$ is amount of anchors installed.

4. The regression model for lateral load capacity for number of anchors installed under tension lateral loads the $\mathrm{P}$ max was $1433+143$. C - 13.02 $\mathrm{C}^{2}$ with a regression coefficient of $\mathrm{R}^{2}=0.517$.

This research can be established with a grant of PHB DP2M Indonesian Directorate General of Higher Education, Universitas Negeri Malang (UM) and Brawijaya University (UB), Malang Indonesia. 


\section{References}

1 Morisco, Teknologi Bambu, (MTBB UGM, Yogyakarta, 2005)

2 Karyadi, B.S. Umniati, Nindyawati, Pengaruh Bentuk Pengekang di Jalur Gaya Tekan Penampang Balok Beton Bertulangan Bambu Terhadap Kapasitas Beban dan Lendutan Balok Pada Rasio Tulangan yang Berbeda, (Fundamental Research Report, DP2M Funding, 2007)

3 Nindyawati, B.S. Umniati, Portal Beton Bertulangan Bambu Yang Dikekang Di Jalur Gaya Tekannya, Sebuah Solusi Pembangunan Rumah Sederhana Tahan Gempa, (PHB Report, DP2M Funding, 2009)

4 Nindyawati, B.S. Umniati, Pengembangan Model Sambungan Balok Kolom Pada Struktur Portal Beton Terkekang Bertulangan Bambu Tahan Gempa, (PHB Report, DP2M Funding, 2011)

5 B.S. Umniati, Karyadi, Pengembangan Model Struktur Beton Bertulangan Bambu Tahan Gempa Sistim Ganda (Kombinasi Portal dan Dinding Geser) Untuk Pembangunan Rumah Sederhana Tahan Gempa pada Wilayah Gempa Tertinggi (Zona 6) di Indonesia, (Hibah Strategis Nasional Research Report, DP2M Funding, 2009)

6 B.S. Umniati, Nindyawati, Pengembangan Model Sambungan Balok Kolom Pada Struktur Portal Beton Terkekang Bertulangan Bambu Tahan Gempa, (Year PHB Report, DP2M Funding, 2012)

7 B.S. Umniati, Nindyawati, Pengembangan Model Sambungan Balok Kolom Pada Struktur Portal Beton Terkekang Bertulangan Bambu Tahan Gempa, Year PHB Report, DP2M Funding, 2013)

8 J.A. Kankam, M.B. George, S.H. Perry, ACI Struct. J. 61 (1988)

9 T. Paulay, M.J.N. Priestley, Seismic Design Of Reinforced Concrete And Masonry Building (John Wiley \& Sons Inc., New York, 1992)

10 S.C. Chun, O. Bohwan, S.H. Lee, J.C. Naito, ACI Struct. J., 579 (2009)

11 S.C. Chun, O. Bohwan, H.S. Lee, T.H.K. Kang, J.W. Wallace, ACI Struct. J., 102 (2007)

12 H.J. Lee, S.Y. Ying, ACI Struct. J., 329 (2009)

13 T.H. Kang, M. Shin, N. Mitra, J.F. Bonacci, ACI Struct. J., 106, 868 (2009

14 D.C. Montgomery, Design and Analysis of Experiments, $5^{\text {th }}$ Edition, (Jhon Wiley \& Sons. Inc., New York, 2001) 